\title{
The impact of foreign exchange movements on Turkish textile sector
}

\author{
DOI: 10.35530/IT.070.03.1591
}

\section{REZUMAT - ABSTRACT}

\section{Impactul mișcărilor de schimb valutar asupra sectorului textil din Turcia}

Datorită importanței lanțului de aprovizionare global și a exporturilor de înaltă tehnologie, importanța noilor piețe în dezvoltare crește treptat. Turcia păstrează poziția strategică pentru sectorul textil, fiind situată în punctul central dintre Balcani, Asia, Orientul Mijlociu, Africa de Nord, Europa de Est și Rusia. Poziția geografică care permite un comerț mult mai avantajos în regiune face ca țara să fie mult mai competitivă decât concurenții săi. Cu toate acestea, devalorizarea și volatilitatea lirei turcești în 2018 au afectat grav sectorul textil din Turcia. Acest studiu urmărește să determine impactul fluctuațiilor cursului de schimb asupra performanțelor firmelor din industria textilă din Turcia între anii 2013 și 2017 . În plus, a fost efectuată o analiză de regresie multiplă pentru a investiga impactul vechimii și mărimii firmei asupra performanței acesteia. Potrivit rezultatelor, volatilitatea cursului de schimb și dimensiunea firmelor au avut un efect negativ asupra performanței firmelor, în timp ce vechimea firmei nu a avut nicio influență semnificativă asupra acestui indicator.

Cuvinte-cheie: schimb valutar, firme din industria textilă, sectorul textil din Turcia, performanța firmelor, valoarea firmelor

\section{The impact of foreign exchange movements on Turkish textile sector}

Due to importance of global supply chain and high-tech exports, importance of new developing markets is gradually increasing. Turkey keeps the strategic importance for textile sector being in the center of Balkans, Asia, Middle East, North Africa, Eastern Europe and Russia. The geographical location allowing trade in the region makes the country much more advantageous than its competitors. However, devaluation and the exchange rate volatility of Turkish Lira in 2018 have been seriously affecting Turkish textile sector. This study aims to determine the impact of exchange rate fluctuation on Turkish textile firms' performance between the years of 2013 and 2017. Additionally, multiple regression analysis was done in order to investigate the impact of firms' performance such as firm age and firm size on performance of the textile firms. According to results, it was observed that exchange rate volatility had a negative effect on the firm performance and the firm size had a negative effect on firm performance while the firm age did not have any influence on firms' performance significantly.

Keywords: exchange rate, textile firms, Turkish textile sector, firm performance, firm value

\section{INTRODUCTION}

Textiles and clothing have been the major products for industrializing countries which played a critical role in Britain, North America, Japan and Turkey for the last two decades. Before the World War II, Western Europe countries and the US controlled the world economy as well as the industrial production. Afterwards, less developed countries took the control of production and providing the raw materials. Industrial textile production totally moved to Japan after 1940's when she became the leader of economic development in the region of Asian. Later on high production costs had compelled for the new investments in other Asian countries such as Japan, Hong Kong, South Korea and Taiwan. During the same period, textile industries in Europe (Germany, Italy, England, France) began to produce at large capacities with the imported yarns provided from the nearest countries such as Turkey. Turkish textile industry has begun its spreading across the country with the foundation of Turkish Republic in 1923. The big state enterprise "Sümerbank" encouraged for sector with the initial developments on textile and apparel sector until it was privatized. The new investments in textile and apparel sector launched after the second half of 1995 when the quantitative restrictions in textile trade between Europe and Turkey were totally eliminated. Turkish textile companies and exporters maintain their presence in the most foreign markets of Europe [1-2]. The geographical location allowing trade in the region makes the country much more advantageous than its competitors. She has the dynamism for taking part in the new growing markets as a result of globalization [3]. The profitability of the markets in the country has improved a lot owing to concentrating on marketing and distribution. It was thought that Turkish Lira depreciation in 2018 and response of Turkish textile sector which is very important among Europe and World textile industry should be evaluated for the possible effects of exchange rate fluctuations on Turkish firms.

\section{FOREIGN EXCHANGE RISK IN TURKISH TEXTILE SECTOR}

\section{Importance of textile on Turkish economy}

There has been an appreciable effect of Turkish textile and clothing sector on Turkey's development and growth for the last 30 years. It is known that sector 
has greatly developed since 1980 when the country put liberal economic policies into operation providing it reaching to foreign markets. Cotton has always become important to the industrial sector of textile as well as to the internal and external trade of Turkey. Turkey has the $8^{\text {th }}$ place after India, China, USA, Pakistan, Brazil, Australia and Uzbekistan among the main cotton fiber growing countries in the world. However, significant drops in the domestic production resulted with the requirement of cotton imports of considerable magnitude, making the country "the fifth largest importer of cotton after Bangladesh, Vietnam, China and Indonesia" in 2016/2017 season according to ICAC estimates [4-6]. Turkey gets the benefits of having the highest fibre and yarn production capacity in Europe. Although China has appeared as a new player for European companies, the certain skills such as flexibility could not meet the European customers who are difficult to be satisfied in terms of response speed, quality and innovation [7]. Textile export which is 16 percent (\%) of total export of the country in 2017 has a prominent influence on Turkish economy. There are about 53,000 operating companies in the sector. Exports of ready to wear items \$17 billion and textiles were \$8 billion in 2017. European countries prefer Turkish textile and garment exporters since those companies work with lowstocks and short response time as well as with high quality. Additionally, low labour wages can be considered as another factor. Germany, Spain, England, Holland and French, Italy, USA, Poland and Denmark are the main exporters of Turkey. According to Turkish Statistical Institute sources under the title of Turkey's foreign trade; Country exports have increased 5.1 times for the last 15 years while the imports have increased 3.6 times during the same period. Table 1 reveals a breakdown of textiles and clothing exports which include cotton exports, together with the share of textiles and clothing exports in the overall exports in Turkey. As it is observed, there is a high contribution of "textiles and clothing" exports to the overall exports of the country. In 1990's, the share of textile and apparel were $30 \%$ of total exports and it gradually decreased to $20 \%$ levels because of the increased share of exports from other sectors such as marble, various industrial minerals, agricultural products and other food products [8].
Over the years, the increase in textile and apparel exports from Turkey has not only provided a growth in industrial exports but also led a reduction in the current trade deficit of Turkey (according to Turkish ministry report 2018; the exporting amount in 2017 was approximately 17 billion Euro whereas the importing amount was approximately 9 billion Euro in Turkish textile). In July 2013, Turkish government emphasized a strong support again for textile industry when the tenth five-year development plan covering the 2014-2018 period which was approved in the Grand National Assembly of Turkey in July 2013. New marketing and production channels have been created. Intelligent and functional textiles have been focused on a lot which are thought to be leading a great impact for Turkish economy. Owing to high value added of the technical textile products and their less vulnerability to price changes, many of the Turkish companies have started technical textile as well as nonwoven production [8].

\section{Exchange rate movements and possible effects on Turkish textile sector}

Owing to the globalization of business environment over the last decade, there is almost no pure domestic company left. Today, foreign exchange risk influences all international trade companies. There are many ways through which the exchange rate movements could affect the firm performance. Cost of imported inputs relative to production factors, export prices, foreign competitors external borrowing costs can be ordered respectively. Generally, an export-oriented firm gets benefit from the depreciation of the local currency whereas import-oriented firms suffer from this situation, which result with increased cost of production and low profits. The impact on firm performance is one of the main component which determines how exchange rate influences total economic growth. Exchange rate fluctuations have vital effect on the companies' profitability. The prices may change due to movements in the exchange rate which will result with the change of competition with domestic exporters and importers. Since the input prices increase for the industries using internationally priced raw materials, total asset of the firms may also change critically in terms of foreign currencies. When considering many industrial organizations in the

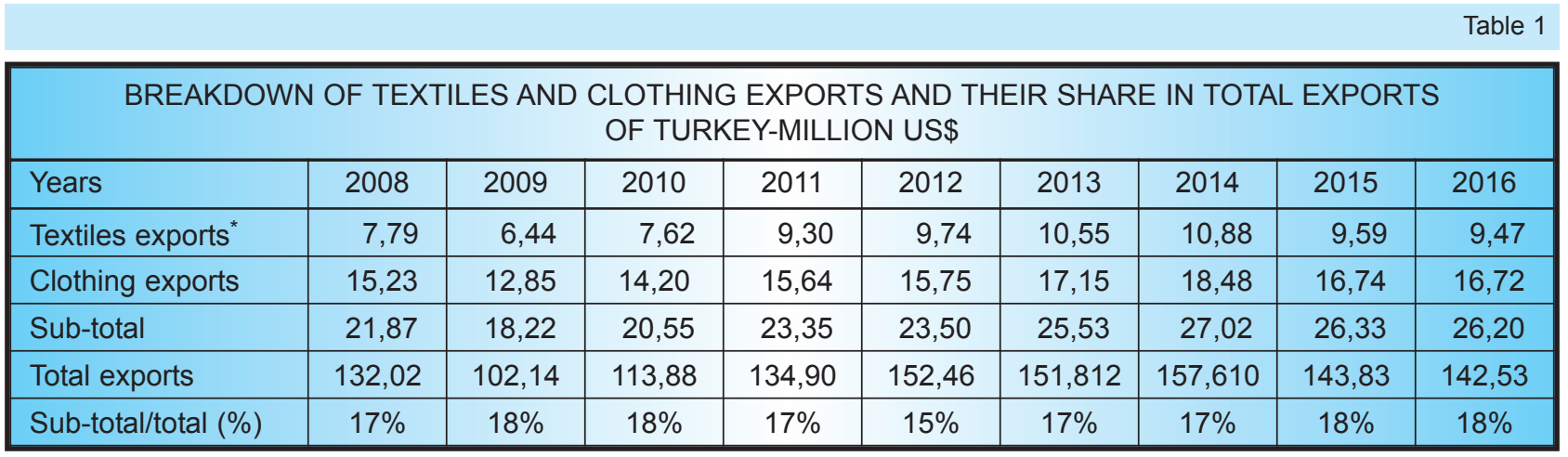

* includes cotton exports; Source: Turkish Statistical Institute (TurkStat). 

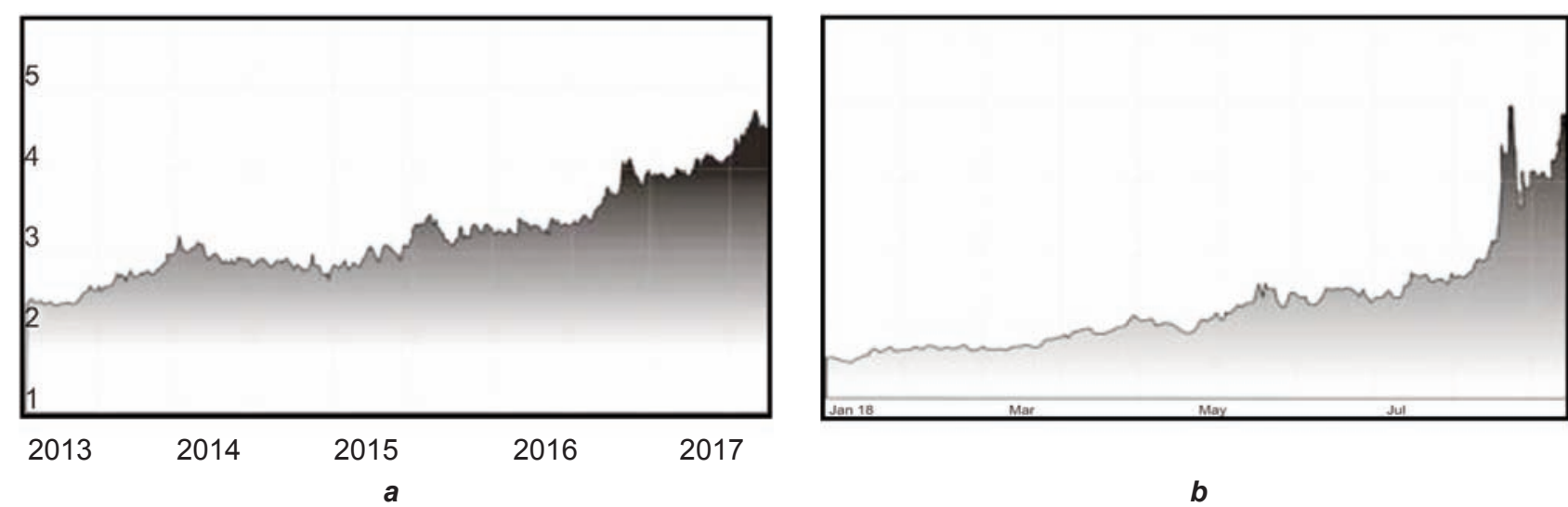

Fig. 1. a - Euro to Turkish Lira Chart (31.12.2013 - 31.12.2017);

$b$ - Euro to Turkish Lira Chart (1 Jan 2018 - 29 June 2018)

country are thought to be in the same position, the country's economic relations in the world are expected to change as well [9]. Most of the studies related to exchange rate fluctuation supports the idea that movement of currency may lead to statistically significant profitability, growth, investment as well as to some trade decreasing effects [10-11]. Previous studies from developed markets indicated some conflicting results with regard to exchange rate risk on firm valuation; Jorion, Amihud, Bortoy and Bodnar concluded that there were no significant correlations between stock prices and exchange rate exposure in USA firms [12-14]. On the other hand, Bodnar and Gentry and Choi and Prasad found that exchange rate movements significantly affected the firm value and company income. Additionally, $\mathrm{He}$ and $\mathrm{Ng}$, Doukas et al., Nydahl declared in their studies that values of Japanese and Swedish firms were significantly were significantly influenced by the exchange rate fluctuations [15-18]. Khoo and Chamberlain et al. studied the values of returns of Australian mining firms and Japanese banking firms were weakly influenced by the exchange rates [19-20]. Kıymaz found that Turkish textile companies were highly exposed to foreign exchange risks and the degree of exposure were generally for textile machineries, chemicals used in treatment processes [21].

Turkish lira (€) has depreciated against Euro $(€)$ for the last 5 years (figure 1, a). 1 Euro was 2.93 Turkish lira in 31.12.2013 whereas it was 4.52 Turkish lira in 31.12 .2017 . The depreciation was around $54 \%$ in 5 years. Figure $1, b$ reveals the value change of Turkish lira against Euro between the dates of 01.01.2018 and 31.08.2018. For the last 8 months, Turkish lira has depreciated from 4.52 to 7.65 against Euro which indicated a depreciation of almost $\% 70$ for Turkish lira only in 8 months. This situation is expected to result with a high risk for the companies. In the last 5 years, the fluctuation of the Turkish lira has increased sharply especially in 2017 and 2018. Turkish lira ( has been seriously depreciated against Euro $(€)$ and the Dollar (\$). The excessive increase and volatility in the exchange rates have caused the attention to focus on foreign exchange debt and foreign exchange position of the real sector. It is recently
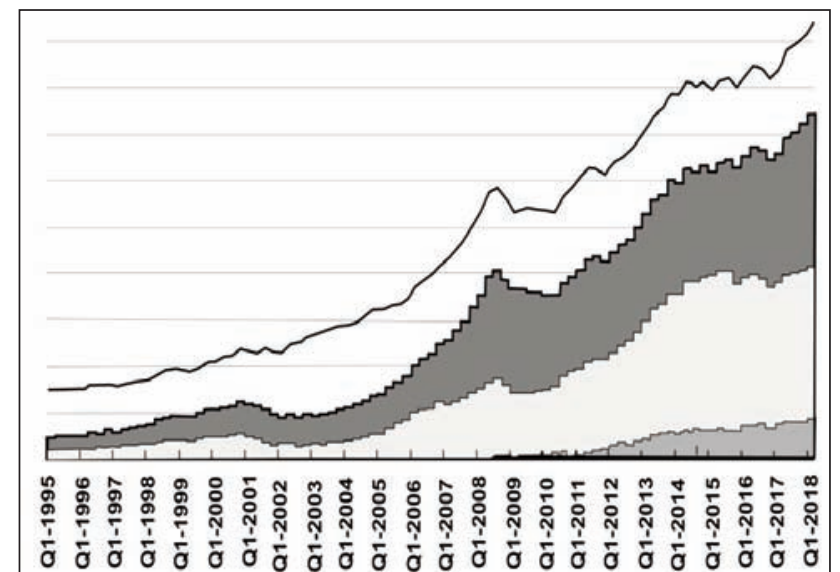

-State Banks $\quad$ Private Banks and Other Financial Institutions Firms $=$ Total

Fig. 2. Turkey external debt

(Source: https://www.cfr.org/blog/framing-turkeys-financialvulnerabilites-some-rhymes-asian-crisis-not-repeat)

emphasized that foreign currency borrowing of Turkey's companies will result with a struggling to repay the foreign currency loans. Today, Turkey's firms have around 287 billion Euro $(€)$ in foreign currency debt. It seems that a number of the firms that took out foreign currency loans don't really have natural hedges. The excessive increase and volatility in the rates will certainly increase the exchange rate expenses so that they may not be afforded by textile companies having debts of foreign exchange, so these companies will start to suffer losses soon as well. Figure 2 reveals Turkey external debt between the years of 1995 and 2018.

This study was thought to be useful with the contribution of analysing the exchange sensitivity of rates through 20 textile companies traded in Borsa Istanbul Corporate Governance Index within the years of 2013-2017. Foreign currency risk sensitivity analysis table was designed for this study. "Foreign currency risk sensitivity analysis table" (table 2) indicates profit before tax which occurs as a result of the foreign exchange gain/loss if Turkish lira ( against foreign currency by $10 \%$ and all other variables remains the same. It is obtained from table 2 that " 17 " of 20 textile firms have exchange risk which 


\begin{tabular}{|c|l|c|c|c|c|c|}
\hline No & \multicolumn{1}{|c|}{ Company name } & $\mathbf{2 0 1 3}$ & $\mathbf{2 0 1 4}$ & $\mathbf{2 0 1 5}$ & $\mathbf{2 0 1 6}$ & $\mathbf{2 0 1 7}$ \\
\hline 1 & AKIN TEKSTIL & $-238,471$ & $-20,447$ & 254,161 & 721,533 & 51,366 \\
\hline 2 & ARSAN TEKSTIL & $-1,163,696$ & $-2,449,072$ & $-2,217,828$ & $-2,237,298$ & $-1,598,777$ \\
\hline 3 & BILICI & 889,791 & $-781,647$ & $-1,390,943$ & $-1,848,672$ & $-1,178,372$ \\
\hline 4 & BIRKO AȘ & $-135,903$ & $-326,302$ & $-319,974$ & $-86,325$ & $-223,759$ \\
\hline 5 & BOSSA & 59,146 & $-1,293,427$ & $-1,397,957$ & $-3,404,728$ & $-3,905,811$ \\
\hline 6 & BIRLIK MENSUCAT & $-347,288$ & $-473,043$ & $-552,218$ & $-777,608$ & $-578,425$ \\
\hline 7 & DAGI & $-1,200,093$ & $-1,032,971$ & $-134,758$ & $-980,779$ & $-858,952$ \\
\hline 8 & DERIMOD & $-417,929$ & $-206,102$ & 103,067 & 83,710 & 117,017 \\
\hline 9 & DESA & $-1,836,234$ & $-1,887,335$ & $-1,900,063$ & $-2,034,719$ & $-5,054,311$ \\
\hline 10 & DIRITEKS & $-232,996$ & $-233,730$ & $-301,936$ & $-317,439$ & $-70,808$ \\
\hline 11 & HATEKS & $-166,193$ & 94,700 & 176,827 & $-641,398$ & $-612,990$ \\
\hline 12 & KARSU & $-1,519,588$ & $-2,596,286$ & $-2,667,606$ & $-3,223,688$ & $-2,459,341$ \\
\hline 13 & KORDSA & $2,342,900$ & 51,418 & $-676,875$ & $-5,389,380$ & $-158,451$ \\
\hline 14 & LUKS KADIFE & $-710,656$ & $-755,320$ & $-623,738$ & $-904,197$ & $-89,649$ \\
\hline 15 & MENDERES TEKSTIL & $-6,499,994$ & $-10,027,515$ & $-11,293,214$ & $-13,027,586$ & $-12,796,809$ \\
\hline 16 & RODRIGO TEKSTIL & 0 & $-55,960$ & $-696,443$ & $-55,839$ & $-42,947$ \\
\hline 17 & SOKTAȘ & $-3,633,528$ & $-4,271,780$ & $-5,036,315$ & $-5,931,261$ & $-4,360,719$ \\
\hline 18 & SONMEZ PAMUK & 247,801 & 179,496 & 240,403 & 864,134 & 279,010 \\
\hline 19 & YATAS CMB & $-561,056$ & $-381,013$ & $-983,149$ & $-779,396$ & $-380,656$ \\
\hline 20 & YUNSA & $-15,630$ & $-418,985$ & $-475,640$ & $-4,773,782$ & $-1,989,460$ \\
\hline & Total loss/gain (Euro) & $-15,139,617$ & $-26,885,321$ & $-29,894,198$ & $-44,744,716$ & $-35,912,843$ \\
\hline
\end{tabular}

the data in table were converted into Euro $(€)$ which is valid for the related year.

has been gradually increasing every year. According to their financial statements in 2017, if Turkish lira ( devaluates $10 \%$, total loss of textile firms will be reaching to $-35,912,843$ Euros. However, Turkish lira has already devaluated $\% 70$ for the last eight months. Hence, the total loss has been already reached to $219,068,342$ Euro $(€)$. Those mentioned firms in table are considerably important with the manner of big exporting capacities as well as for becoming the major importers in terms of raw material supply from the world countries. For instance, "Menderes" textile company which has $81 \%$ export capacity among the products and which is the major producer of "IKEA" has a very high foreign exchange gap. "Yünsa" which is the lead fabric supplier to many world textile brands has customers in more than 50 different countries. The company has many offices located in Germany and England. So the possible financial problems of those firms will not only affect the Turkish textile sector but all world textile market.

\section{RESULTS OF DISCUSSION}

46 Turkish textile companies are included in the list of biggest companies in ISO 500. 20 of 46 textile companies are traded in Borsa Istanbul. Within this study, the dates of those 20 firms were used between the years of 2013 and 2017.

Study Variables and Hypothesis: This study assumes that textile firms' performance is influenced by exchange rate and firms' characteristics. The dates for measuring the financial performance of the firms were obtained from the secondary sources (the annual reports of firms were published by Turkish Public Disclosure (KAP). Within the analyse, firm's performance is selected as the dependent variable whereas exchange rate, firm size and firm age is selected as the independent variables. Return on Assets (ROA) was used for measuring the firm performance. This popular ratio has been used widely for the past, present and future strategic decisions in early studies. ROA can be calculated by dividing net income after taxes on the Assets. Exchange rate, firm size and firm age are selected as the independent variables. In this study, exchange rate is selected as from Euro to Turkish lira (ఓ). From Dollar to Turkish lira (ఓ) was omitted in the model owing to the possible multi collinearity between the Euro and Dollar. Exchange rate exposure is known to be influencing the firms' performance regarding to early literature [22-25]. Firm size which may affect the firm performance in many aspects is selected as one of the other independent variable of the model. Early studies also support our hypothesis where size was correlated with market power. When considering firm ages; older firms are known to have more experience which determine their response for the exchange rate shocks and financial constraints [25-29].

Regression Model: ROA $=\alpha_{0}+\beta_{1}$ Log Exchange

Rate (LER) $+\beta_{2}$ Log Size (LS) $+\beta_{3}$ Age $+\varepsilon_{\mathrm{t}}$ $\mathrm{H}_{0}=$ there is no significant impact for exchange rate on firm's performance; $H_{0}{ }^{\prime}=$ there is no significant impact for size on firm's performance; $\mathrm{H}_{0}$ " = there is no significant impact for age on firm's performance. 


\begin{tabular}{|c|c|c|c|c|c|c|c|c|c|c|c|}
\hline \multicolumn{4}{|c|}{ Descriptive statitics } & \multicolumn{4}{c|}{ Pearson correlation results } \\
\hline & Minimum & Maximum & Mean & St. Deviation & Skewness & Kurtosis & & ROA & LER & LS & AGE \\
\hline ROA & -12 & 0.10 & 0.01 & 0.06 & -0.27 & -0.56 & ROA & 1 & $0.574^{* *}$ & $-0.187^{*}$ & 0.043 \\
\hline LER & 0.85 & 1.31 & 1.07 & 0.114 & -0.353 & -0.419 & LER & & 1 & 0.065 & $0.176^{*}$ \\
\hline LS & 4.31 & 15.43 & 8.56 & 0.821 & -0.543 & -0.231 & LS & & & 1 & 0.122 \\
\hline Age & 20 & 66 & 44.83 & 12.98 & -0.06 & 0.21 & Age & & & 1 \\
\hline
\end{tabular}

Table 4

\begin{tabular}{|c|c|c|}
\hline \multirow{2}{*}{ Dependent variable } & \multicolumn{2}{|c|}{ ROA } \\
\cline { 2 - 3 } & B. & sig. \\
\hline LER & -0.0274 & 0 \\
\hline LS & -0.0052 & -0.024 \\
\hline AGE & 0.768 & 0.549 \\
\hline Adj.R R $^{2}$ & \multicolumn{2}{|c|}{0.345} \\
\hline F Stat. & \multicolumn{2}{|c|}{10.43} \\
\hline Model Sig. & \multicolumn{2}{|c|}{0} \\
\hline D-W & \multicolumn{2}{|c|}{0.894} \\
\hline
\end{tabular}

Statistical Analysis: Before analyzing the hypothesis, descriptive analysis was conducted in order to explain the dates (table 3). According to table 3 , it is observed that ROA is $1 \%$ and the average firm age is approximately 45 years. Additionally, the average firm's size measured by the logarithm was found as 8.5. Table 4 indicates the Pearson correlation results where there is no multi collinearity relationship between the independent variables. Additionally, the primary results show that there is a significant relationship between ROA and LER and LS. These primary results will be re-tested by multiple regression analysis.

The specific assumptions must be provided for the evaluation of Multiple Regression. The first assumption related to multicollinearity, Pearson Correlation in table 3 indicated that there is no perfect relation between the independent variables. The second assumption is related to independent error. The Durbin Watson test (D-W) was used to conduct the test. According to table 4 , the results were found in the accepted range between 0 and 4 . The sample size is one of another multiple regression assumption. 10 observations were used within the study for each independent variable which is accepted according to according to Hair et al. [30]. Normality is the other assumption where skewness and kurtosis was used for testing it. The descriptive statistics table 3 supports that the results are within the accepted range, between -1 to 1 for Skewness and -3 to 3 for Kurtosis [31]. Table 4 indicates "Regression results of foreign exchange rate, size and age on firms' performance". According to regression results (table 4) it was observed that exchange rate volatility had a negative effect on the firm performance. The firm size had a negative effect while the firm age did not have any influence on firms' performance significantly.

\section{CONCLUSIONS}

Turkey has free-floating exchange rate markets which are not completely fixed by the government. $70 \%$ Approximate Devaluation of Turkish Liras in 2018 have noticeably influenced the Turkish textile sector. This study supports that some of the big Turkish textile companies carry the risk of profit loss or facing problems during the repayment of their debt due to high devaluation in Turkish Lira. According to table 2, 17 of 20 Turkish textile companies traded in Borsa İstanbul have foreign exchange gap. Also the regression analysis indicated that exchange rate movements led to decrement of financial performance of the firms with profit loss. It is advised for the mentioned firms to hedge the currency debt and credits in derivative markets as a precaution. Additionally, they should protect themselves from the possible foreign exchange risks by futures, forward, option and swap contracts. Another prominent result of the study is the profit loss as the firm size increased. This result indicates that the firms may suffer from some problems during the new strategic decisions, modernization and fast adaptation to the innovations. The firms should be able to move faster in the markets.

\section{BIBLIOGRAPHY}

[1] Atilgan, T., \& Kanat, S. The effects of the EU customs union with Turkey on the Turkish textile and clothing sector, In: Fibres \& Textiles in Eastern Europe, 2006, 4 (58), pp. 11-15.

[2] "World trade and GDP growth in 2016 and early 2017", In: World Trade Statistical Review (World Trade Organization), 2017, pp. 16-24.

[3] Ozturk, H. K. Energy usage and cost in textile industry: A case study for Turkey, In: Energy, 2005, 30(13), pp. 2424-2446.

[4] Atılgan, T. Effects of Textile and Clothing sector on the economy of Turkey, In: Fibres \& Textiles in Eastern Europe October / December 2006, Vol. 14, No. 4, p. 58

[5] International Cotton Advisory Committee (ICAC), "February Monthly Report", In: International Cotton Advisory Committee (ICAC), Washington, DC 20006 USA, 2016. 
[6] Karaalp, H. S., \& Yilmaz, N. D. Assessment of trends in the comparative advantage and competitiveness of the Turkish textile and clothing industry in the enlarged EU market, In: Fibres \& Textiles in Eastern Europe, 2012, No. 3 (92), pp. 8-12.

[7] Asalos, N., \& Lordanescu, M. The contribution of clusters to increase the competitiveness of the textile and clothing industry. Cluster analysis using location quotient method/Contributia clusterelor la cresterea competitivitatii industriei textile si de confectii. Analiza acestora prin metoda coeficientului de localizare, In: Industria Textila, 2015, 66(6), p. 370.

[8] TUIK (TURKISH STATISTICAL INSTITUTE), «http://www.tuik.gov.tr/PreTablo.do?alt_id=1001,» [Online]. [Date of access: 1406 2018].

[9] Nagahisarchoghaei, M., Nagahi, M., \& Soleimani, N. Impact of exchange rate movements on Indian firm performance, In: International Journal of Finance and Accounting, 2018, 7(4), pp. 108-121, DOI: 10.5923/j.ijfa.20180704.03.

[10] Aizenman, J., Edwards, S., \& Riera-Crichton, D. Adjustment patterns to commodity terms of trade shocks: the role of exchange rate and international reserves policies, 2012, In: Journal of International Money and Finance, 31, (8), pp. 1990-2016.

[11] Greenaway, D., Kneller, R., \& Zhang, X. The effect of exchange rates on firm exports: The role of imported intermediate inputs, In: The World Economy, 2010, 33(8), pp. 961-986.

[12] Jorion, P. The exchange-rate exposure of US multinationals, In: Journal of business, 1990, pp. 331-345.

[13] Amihud, Y., Levich, R. Exchange rates and the valuation of equity shares, In: Exchange Rates and Corporate Performance, Irwin, New York, 1994, pp. 49-59.

[14] Bartov, E. and Bodnar, G. M. Firm valuation, earnings expectations, and the exchange rate exposure effect, In: Journal of Finance, 1994, Vol. 49, pp. 1755-85.

[15] Bodnar, G. M., Gentry, W.M. Exchange rate exposure and industry characteristics: evidence from Canada, Japan, and the USA, In: Journal of International Money and Finance, 1993, February, pp. 29-45.

[16] He, J. and $\mathrm{Ng}$, L. The foreign exchange exposure of Japanese multinational corporations, In: Journal of Finance, Vol. 53, 1998, pp. 733-53.

[17] Doukas, J., Hall, P. H. and Lang, L. H. P. The pricing of currency risk in Japan, In: Journal of Banking and Finance, 1999, Vol. 23, pp. 1-20.

[18] Nydahl, S. Exchange rate exposure, foreign involvement and currency hedging of firms: some Swedish evidence, In: European Financial Management, 1999, Vol. 5, pp. 241-57.

[19] Khoo, A. Estimation of foreign exchange exposure: an application to mining companies in Australia, In: Journal of International Money and Finance, 1994, vol. 13, issue 3, pp. 342-363

[20] Chamberlain, S., Howe, J. and Popper, H. The exchange rate exposure of US and Japanese banking institutions, In: Journal of Banking and Finance, 1997, Vol. 21, pp. 871-92.

[21] Kiymaz, H. Estimation of foreign exchange exposure: an emerging market application, In: Journal of Multinational Financial Management, 2003, 13(1), pp. 71-84.

[22] Choi, J. J., \& Prasad, A. M. Exchange risk sensitivity and its determinants: a firm and industry analysis of US multinationals, In: Financial Management, 1995, pp. 77-88.

[23] McGuire, J. B., Sundgren, A., \& Schneeweis, T. Corporate social responsibility and firm financial performance, In: Academy of management Journal, 1988, 31(4), pp. 854-872.

[24] Kobeissi, N. (2004, March). Ownership structure and bank performance: evidence from the Middle East and North Africa. Economic Research Forum.

[25] Adler, M., \& Dumas, B. (1984). Exposure to currency risk: definition and measurement, In: Financial management, pp. $41-50$.

[26] Jorion, P. The exchange-rate exposure of US multinationals, In: Journal of business, 1990, pp. 331-345

[27] Shepherd, W. G. (1986) On the Core Concepts of Industrial Economics, In: H.W. De Jong and W. G. Shepherd, eds, Mainstreams in Industrial Organization. Dordrecht: Martinus Nijhoff Publishers.

[28] Leibenstein, H. (1976) Beyond Economic Man. Cambridge, MA: Harvard University Press.

[29] Nagahisarchoghaei, M., Nagahi, M., \& Soleimani, N. Impact of Exchange Rate Movements on Indian Firm Performance, In: International Journal of Finance and Accounting 2018, 7(4): pp.108-121, DOI: 10.5923/ j.ijfa.20180704.03.

[30] Hair.Jr., J. F., Black., W. C., Babin., B. J., Anderson., R. E., \& L.Tatham., R. (2006). Multivariant Data Analysis. In: New Jersey: Pearson International Edition.

[31] Jain, T.R. \& Aggarwal Dr. S.C. 2008. Quantitative methods for MBA. New Delhi: V.K. (India) Enterprises

\section{Authors:}

\section{YUSUF KAYA ${ }^{1}$, GIZEM GÜNAYDIN KARAKAN ${ }^{1,2}$, EMILIA VISILEANU ${ }^{3}$}

${ }^{1}$ Pamukkale University, Buldan Vocational School, Accounting Programme, 20400, Buldan, Denizli, Turkey 2Pamukkale University, Buldan Vocational School, Fashion\&Design Programme, 20400, Buldan, Denizli, Turkey

${ }^{3}$ The National Research and Development Institute for Textiles and Leather, 030508, Bucharest, Romania e-mail: ykaya@pau.edu.tr; ggunaydin@pau.edu.tr

Corresponding author:

YUSUF KAYA

e-mail: ykaya@pau.edu.tr 